\title{
Analisis Persepsi, Preferensi, dan Ekspektasi Perancangan Children Playground Panti Asuhan Salib Putih Salatiga
}

\author{
Yeni Setiyawan ${ }^{1^{*}}$, Endang Pudjihartati ${ }^{1}$ \\ 1. Prodi Agroteknologi, Fakultas Pertanian Universitas Kristen Satya Wacana, Indonesia
}

*E-mail: 512014047@student.uksw.edu

\begin{abstract}
Analysis of perceptions, preferences, and expectations for the design of the children playground at the Salib Putih Orphanage in Salatiga. Playing is a need for children that must be fulfilled. Children can improve gross and fine motoric development, improve reasoning, and understand their environment, shape their imagination, fantasy power, and creativity by playing. At this time, the Salib Putih Orphanage did not have a special play area for children, the children play in the yard and hall. This study aims to determine the potential and constraints on the site of the Salib Putih Orphanage and to determine the perceptions, preferences, and expectations of stakeholders in the orphanage regarding the design of the children playground which can then be used as input in designing the play area at the Salib Putih Orphanage. The research stages included site surveys, interviews with orphanage caregivers and foundation administrators as well as questionnaires to 40 respondents covering the residents of orphanages, the children and adolescents, with educational levels ranging from elementary school, junior high school to higher education, the orphanage foundation staff and workers, also the practical students at the orphanage. Site survey includes location, boundaries, accessibility, climate. Interviews use the in-depth interview method, which is the process of extracting information in depth, openly, and free of problems and research focus, while the questionnaire for respondents using the Likert measurement scale is presented with several questions that must be filled, given 5 choices that have gradations levels from Strongly Disagree, Disagree, Neutral, Agree to Strongly Agree. Each of these answer choices has a weighted value of 1-5 points. The results showed that the site in the area of the Salib Putih Orphanage has the potential to build a children's playground with a variety of facilities and supports in accordance with the analysis of perceptions, preferences, and expectations.
\end{abstract}

Keywords: lansdscape design, open space, children's play activities

\section{Pendahuluan}

Sejak kecil manusia selalu melakukan aktivitas bermain karena bermain selalu membawa keriangan, kesenangan dan kegembiraan bagi yang melakukannya. Aktivitas bermain selain menciptakan kegembiraan bagi manusia, juga dapat mengembangkan kemampuan kognitif, sosial, fisik, serta kemampuan emosional yang selalu dibutuhkan saat tumbuh menjadi dewasa. Secara ilmiah aktivitas bermain sangat menunjang bagi perkembangan anak-anak seperti belajar dan beradaptasi dengan perkembangan indranya (Rodger dan ziviani,2006). Selain itu, anak-anak juga lebih mampu berintraksi, berhubungan dengan teman sebaya, berdasarkan hal tersebut aktivitas bermain anak-anak telah menjadi suatu hak yang harus dipenuhi untuk menunjang perkembangan kehidupan sebelum dewasa. Menurut Asmawati (2011), melalui fasilitas bermain terlihat adanya suatu interaksi yang berkesinambungan antara manusia dan lingkunganya. Brown (2003) mengatakan bahwa bermain adalah alat dasar anak untuk menjelajahi dunia, lingkungannya, hubungan interpersonal dan fisik mereka, dan perasaan diri mereka selama bermain anak-anak memperoleh pemahaman yang tulus tentang realitas dan dunia di sekitar mereka. Dengan cara melakukan pendekatan bermain, anak-anak mampu mengembangkan aspek psikis dan fisik mereka. Sehingga perlu adanya sebuah area khusus bagi anak-anak di Panti Asuhan Salib Putih untuk meningkatkan perkembangan berbagai aspek tersebut yang dapat diwujudkan dengan menydiakan sebuah area bermain anak berupa Children Playground.

Dengan rata-rata penghuni Panti Asuhan Salib Putih yang merupakan usia anak-anak dan remaja, sehingga sangat peting bagi pihak Yayasan khususnya Panti Asuhan Salib Putih untuk menyediakan area yang di khususkan untuk bermain. Tahap pertama dalam penelitian ini adalah melakukan melakukan obsevasi pada tapak untuk mengetahui berbagai aspek biofisik, kondisi eksisting, potensi dan kendala pada tapak. Informasi yang didapat dalam tapak tersebut kemudian dianalisis untuk meghasilkan rancangan sebagai dasar pengajuan ijin kepada pihak Yayasan. Saat ini Panti Asuhan Salib Putih belum memiliki fasilitas bermain untuk 
anak-anak secara khusus, sehingga diperlukan kegiatan penelitian ini untuk mengetahui kondisi eksisting tapak, potensi dan kendala biofisik serta mengetahui persepsi, preferensi dan ekspektasi baik pengguna dan pengelola terhadap perancangan rancangan Children Playground Panti Asuhan Salib Putih.

\section{Metode}

\subsection{Lokasi Penelitian}

Penelitian ini dilaksanakan pada bulan Oktober 2020-Januari 2021 di wilayah Yayasan Sosial Kristen Salib Puth Salatiga khususnya pada unit layanan Panti Asuhan yang secara geografis terletak di lereng Gunung Merbabu beralamat di Jl. Salatiga-Kopeng Km 4, Kelurahan Kumpulrejo Kecamatan Argomulyo Kota Salatiga.

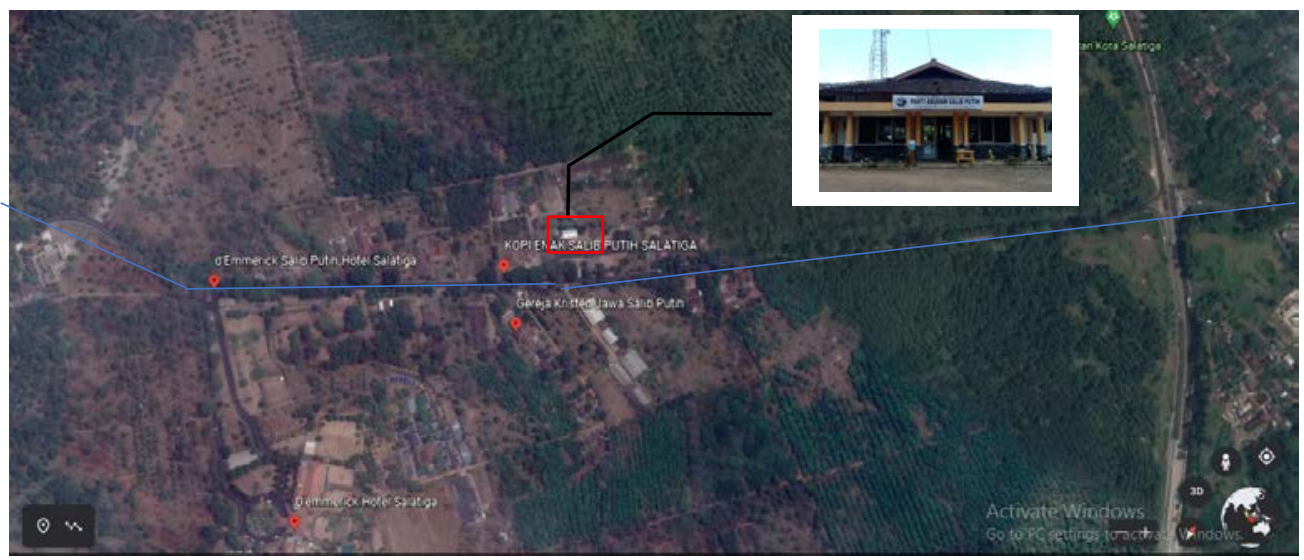

Gambar 1: Wilayah Salib Putih Salatiga \& Lokasi Perencanaan

(Sumber: Google Earth, 2021)

\subsection{Metode Penelitian}

Penelitian ini diawali dengan tahapan persiapan berupa perizinan ke pihak Yayasan Sosial Kristen Salib Putih dimana Panti Asuhan Salib Putih sendiri bernaung, Inventarisasi biofisik meliputi letak, batas, aksesibilitas, topografi, dan iklim. Untuk data seperti letak dan aksesibilitas dikategorikan data primer yang di peroleh dari observasi di lapangan. Inventarisasi dilakukan untuk mengetahui apa saja potensi dan kendala pada tapak. Letak berisi koordinat dari tapak dan aksesibilitas berisikan mengenai kemudahan tapak untuk di jangkau dan dicapai oleh jaringan transportasi serta kondisi umum seperti good view dan bad view, kondisi geografis luasan dan akses menuju tapak. Untuk data topografi dan iklim diperoleh dari data sekunder melalui studi pustaka dan Yayasan Sosial Kristen Salib Puth.

Untuk mengetahui persepsi dilakukan wawancara kepada pengurus Yayasan dan pengurus Panti Asuhan serta kuisioner kepada penghuni Panti Asuhan dan beberapa orang yang berada disana atau bekerja di sana. Wawancara menggunakan metode in-depth interview, menurut Moleong (2005), wawancara mendalam (in-depth interview) merupakan proses menggali informasi secara mendalam, terbuka, dan bebas dengan masalah dan fokus penelitian dan diarahkan pada pusat penelitian, dalam hal ini metode wawancara mendalam yang dilakukan dengan adanya beberapa daftar poin pertanyaan yang telah dipersiapkan meliputi seberapa penting keberadaan area bermain untuk anak-anak, pemilihan fasilitas utama dan pendukung, sampai dengan mengenai sumber pendananaan untuk pengadaan Children Playground nantinya. Wawancara diajukan kepada pengurus Yayasan dan Pengasuh Panti Asuhan, dimana proses memperoleh keterangan dengan pedoman wawancara yang telah disiapkan. Wawancara juga bertujuan untuk mendapatkan tujuan dari perencanaan dan masalah-masalah apa saja yang terdapat dalam perencanaan.

Untuk mengetahui preferensi dan ekspektasi digunakan kuisioner dengan responden sebanyak 40 orang terdiri dari anak-anak Panti Asuhan yang duduk dibangku SMP sampai dengan Perguruan Tinggi, tenaga kerja di Panti Asuhan, Mahasiswa praktek di Panti Asuhan, serta beberapa orang yang berada dilingkup Panti Asuhan. Jenis skala interval yang digunakan dalam penelitian ini adalah skala Likert. Skala Likert adalah skala yang menunjukkan seberapa kuat tingkat setuju atau tidak setuju terhadap suatu pernyataan, para 
responden di sajikan beberapa pertanyaan yang harus diisi, dengan 5 pilihan skala likert yang memiliki gradasi tingkatan dari Sangat Tidak Setuju, Tidak Setuju, Netral, Setuju sampai dengan Sangat Setuju, setiap pilihan jawaban tersebut memiliki bobot nilai dari 1-5 poin.

\subsection{Metode Analisis Data}

Metode analisis data meliputi tahapan pengolahan data hasil survei tapak, wawancara serta kuesioner dengan metode yang dihunakan adalah tabulasi, pembobotan, dan deskriptif.

\section{Tabulasi}

Metode pengolahan data hasil kuesioner penelitian ini adalah tabulasi data dalam bentuk penilaian bobot sesuai dengan kategori skala yang telah di tentukan (nilai jenjang interval) dan disajikan dalam bentuk angka. Teknik tabulasi data ini digunakan untuk mengukur seberapa penting fasilitas utama dan fasilitas pendukung untuk di sematkan dalam desain nantinya.

2. Pembobotan

Setiap variable penelitian diukur menggunakan instrument pengukur dalam bentuk kuesioner berskala ordinal yang memenuhi persyaratan tipe Skala Likert. Menurut Sugiyono (2017) yang dimaksud dengan Skala Likert adalah skala yang digunakan untuk mengukur sikap, pendapat, dan persepsi seseorang atau sekelompok orang tentang fenomenal sosial. Bobot nilai yang diberikan pada tiap gradasi tingkatan adalah sebagai berikut:

a. Sangat setuju $=5$

b. Setuju $=4$

c. Netral $=3$

d. $\quad$ Tidak setuju $=2$

e. Sangat tidak setuju $=1$

Keterangan:

NIJ (nilai jenjang interval) $=\frac{\text { nilai tertinggi-nilai terendah }}{\text { jumlah } \text { kriteria pernyataan }}$

$$
\begin{array}{lll}
\text { Nilai terendah } & : 1 & \\
\text { Nilai tertinggi } & : 5 & \\
\text { Interval } & : 5-1 & =4 \\
\text { Jarak interval } & :(5-1): 5 & =0.8
\end{array}
$$

Tabel 1: Kategori Skala

\begin{tabular}{ccc}
\hline \multicolumn{2}{c}{ Skala } & Kategori \\
\hline 1. & 1.8 & Sangat Tidak Perlu \\
1.8 & 2.6 & Tidak Perlu \\
2.6 & 3.4 & Netral \\
3.4 & 4.2 & Perlu \\
4.2 & 5 & Sangat Pelu \\
\hline *Sumber: Sugiyono 2014 &
\end{tabular}

Berikut adalah garis kontinum yang digunakan untuk memudahkan dalam melihat kategori penilaian variable yang ditentukan

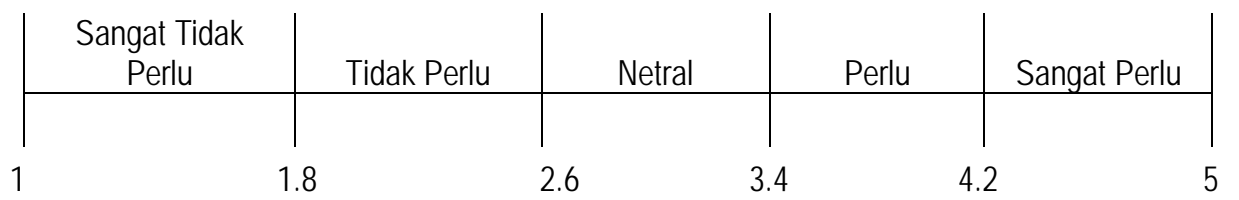

3. Deskriptif

Analisis diskriptif dilakukan dengan menganalisis data dengan cara mendiskripsikan atau mengambarkan data yang telah dikumpulkan dilengkapi tabel ataupun gambar. 


\section{Hasil dan Pembahasan}

\subsection{Kondisi Eksisting Tapak dan Aspek Biofisik}

Panti Asuhan Salib Putih Salatiga merupakan salah satu unit layanan Yayasan Sosial Kristen Salib Putih yang di dirikan oleh Abraham Theodorus Jakobus Van Emmrick dan Alice Cleverly dari Belanda pada tahun 1902. Panti Asuhan ini berada pada jalur pertintasan menuju wisata Kopeng Kabupaten Semarang, beralamat di jalan Hasanudin Km.4 Salib Putih Salatiga Kel. Lumpulrejo, Kec.Argomulyo secara geografis terletak di lereng gunung Merbabu sehingga udara yang dihasilkan sangat sejuk dan bersih. Panti Asuhan Salib Putih Salatiga terletak di70 21'34"S dan 110'28'42"E dengn ketinggian tempat 746 mdpl dan dengan luasan sebesar $116 \mathrm{~m}^{2}$.

Batas wilayah Panti Asuhan Salib Putih adalah pada sebelah Utara wilayah salib putih berbatasan dengan Kelurahan Tegalrejo Kota Salatiga, sebelah selatan berbatasan langsung dengan Kecamatan Getasan Kabupaten Semarang, sedangkan pada sebelah timur wilayah Salib Puth berbatasan dengan Keluragan randuacir kota Salatiga, dan pada sebelah barat wilayah Salib Putih berbatasan dengan kecamatan Sidomukti Kota salatiga. Jenis transportasi yang dapat digunakan untuk menjangkau lokasi Panti Asuhan Salib Puth Salatiga adalah kendaraan pribadi ronda dua maupun roda empat, transportasi umum berupa bis antar kota, angkutan umum dan ojek online. Dapat di lihat pada gambar 1 yang dilihat melalui Goole Earth garis yang berwarna biru menunjukan akses menuju lokasi Panti Asuhan Salib Putih Salatiga, sedangkan garis merah menunjukan lokasi Panti Asuhan Salib Putih Salatiga berada.

Kendala pada tapak saat ini yang dapat dijumpai yakni pada akses masuk menuju Panti Asuhan Salib Putih atau pada gerbang masuk perkerasan jalan memang sudah ada akan teteapi masih bergelombang dan belum rata sehingga dapat membahayakan pengunjung Panti Asuhan terutama yang menggunkan transportasi roda dua, sedangkan untuk akes keluar atau gerbang untuk keluar belum mendapatkan sentuhan perkerasan jalan sehingga pada kondisi hujan sangat licin dan dapat membahayakan.

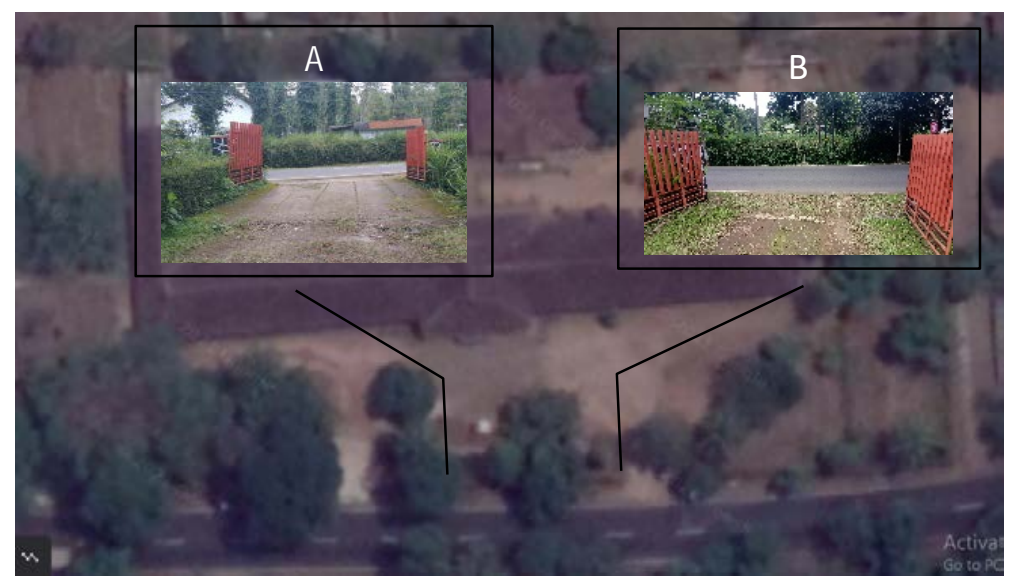

Gambar 2: Akses Masuk (a) dan Akses Keluar (b) Belum Mendapatkan Perkerasan Jalan Secara Keseluruhan Sehingga Licin Saat Terjadi Hujan

(Sumber: Google Earth, 2021)

Lokasi Panti Asuhan Salib Putih yang berdekatan langsung dengan jalan raya antar kota membuat tingkat kebisingan yang dirasakan relativ cukup tinggi. Pasokan air bersih juga menjadi kendala menurut pengasuh Panti Asuhan, saat ini hanya mengandalkan pasokan air dari PDAM setempat, seringkali air juga mati maka dari itu pihak Yasasan menyediakan beberapa toren atau tandon air sebagai penampungan air bersi, pihak Yayasan juga beberapa kali berupaya membangun sumur bor akan tetapi sumber air tidak kunjung dapat ditemukan. Pada tapak bagian dalam atau halaman dalam Panti Asuhan Salib Putih output untuk drainase bisa dikatakan belum bisa mengakomodir debit air hujan dengan maksimal sehingga saat hujan datang dengan intensitas tinggi seringkali halaman belakang terendam air hujan. 


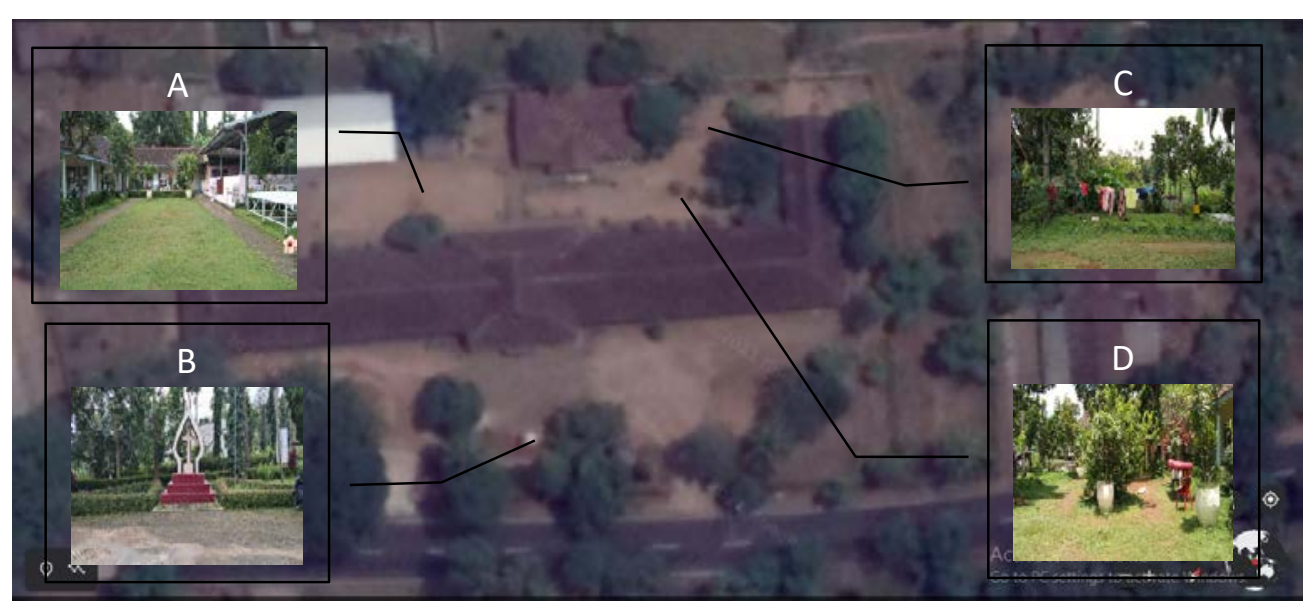

Gambar 3: Halaman Belakang (a), Tugu Peringatan 100 Tahun yang Dikelilingi Taman dan Menjadi Poin Good View (b), Space yang Digunakan untuk Menjemur Pakaian (c) dan Tanaman Jeruk Lemon yang Berada di Tengah-Tengah Halaman Menjadi Poin Bad View (d)

(Sumber: Google Earth, 2021)

Table 2. Data Curah Hujan 2012-2019

\begin{tabular}{cc}
\hline Jumlah curah hujan per tahun \\
\hline 2012 & 2025.00 \\
2013 & 1571.00 \\
2014 & 1920.00 \\
2015 & 2876.00 \\
2016 & 2124.00 \\
2017 & 2571.00 \\
2018 & 2718.00 \\
2019 & 2030.00 \\
\hline Jumlah & 2229.38 \\
\hline
\end{tabular}

*Sumber: BPS Kota Salatiga, 2021

Panti Asuhan Salib Putih memiliki suhu udara $25^{\circ} \mathrm{C}$ dengan Curah hujan $2229 \mathrm{~mm} / \mathrm{tahun}$ yang dapat dilihat pada Table 2 yang berisikan data curah hujan yang diambil antara kurun waktu 2010 sampai dengan 2019 (BPS Kota Salatiga,2020). Dengan suhu udara tersebut dapat terbilang nyaman dimana hal tersebut sesuai dengan standar suhu kenyamanan manusia. Menurut Lippsmeier (1994) iklim berpengaruh pada kenyamanan yang dirasakan manusia beberapa peneliti yang membuktikan batas kenyamanan (dalam Temperatur Efektif/TE) berbeda-beda tergantung pada letak geografis dan subjek manusia di berbagai negara, di Indonesia sendiri batas kenyamanan manusia sendiri berkisar di angka $20^{\circ} \mathrm{C}-26^{\circ} \mathrm{C} \mathrm{TE}$.

Jenis tanah pada kawasan Panti Asuhan Salib Putih adalah jenis tanah Andosol coklat, menurut hasil studi pustaka jenis tanah ini cocok untuk budidaya tanaman, pangan, dan perkebunan maka tidak heran bila di Kawasan Salib Putih ini sendiri juga terdapat perkebunan karet, kopi, dan sayuran serta Hotel karena memang kawasan Salib Putih ini sangat berpotensi untuk dikembangkan dengan berbagai potensi yang sudah ada. Berikut adalah table analisis potensi dan kendala pada tapak aspek biofisik disajikan dalam tabel 3. 
Tabel 3. Analisis Potensi dan Kendala Tapak

\begin{tabular}{|c|c|c|c|c|}
\hline \multirow[t]{2}{*}{ No } & \multirow{2}{*}{$\begin{array}{l}\text { Aspek } \\
\text { Biofisik }\end{array}$} & \multirow[t]{2}{*}{ Data } & \multicolumn{2}{|c|}{ Analisis } \\
\hline & & & Potensi & Kendala \\
\hline 1 & Lokasi & $\begin{array}{l}\text { 70 21'34"S dan } 110^{\circ} \\
\text { 28'42"E }\end{array}$ & $\begin{array}{l}\text { Lokasi tapak strategis } \\
\text { di jalur perlintasan } \\
\text { wisata Kopeng }\end{array}$ & $\begin{array}{l}\text { Merupakan jalur perlintasan } \\
\text { wisata kopeng sehingga } \\
\text { tingkat kebisingannya cukup } \\
\text { tinggi }\end{array}$ \\
\hline 2 & Tanah & Jenis tanah Andosol Coklat & $\begin{array}{c}\text { Cocok untuk budidaya } \\
\text { tanaman }\end{array}$ & Tanah mudah longsor \\
\hline 3 & Iklim & $\begin{array}{c}\text { Suhu udara } 25 \circ C \text { dengan } \\
\text { Curah hujan } 2229.38 \\
\text { mm/tahun selama 2012- } \\
2019\end{array}$ & Iklim cukup sejuk & $\begin{array}{c}\text { Cuaca sering tak menentu } \\
\text { (agak panas dikala siang } \\
\text { dan sangat dingin dikala } \\
\text { malam) }\end{array}$ \\
\hline 4 & $\begin{array}{l}\text { Aksesbilitas } \\
\text { dan Sistem } \\
\text { Transportasi }\end{array}$ & $\begin{array}{l}\text { Merupakan jalan raya antar } \\
\text { kota, dan kabupaten, } \\
\text { Memasuki area panti } \\
\text { asuhan sudah } \\
\text { menggunakan perkerasan } \\
\text { jalan cor beton, paving, dan } \\
\text { sebagian besar masih }\end{array}$ & $\begin{array}{l}\text { Jalan utama sudah } \\
\text { aspal dan dalam } \\
\text { kondisi baik, } \\
\text { Mobil pribadi dan } \\
\text { sepeda motor dapat } \\
\text { masuk area panti }\end{array}$ & $\begin{array}{l}\text { Jalan cukup besar dan } \\
\text { ramai dengan kendaraan } \\
\text { Perkerasan jalan masih } \\
\text { belum sepenuhnya } \\
\text { dibangun, terutaman pada } \\
\text { gebang untuk keluar }\end{array}$ \\
\hline & & berupa tanah & asuhan & $\begin{array}{c}\text { Pada gerbang aksek keluar } \\
\text { panti sangat licin saat }\end{array}$ \\
\hline & & Jenis transportasi pada & & musim hujan karena belum \\
\hline & & $\begin{array}{l}\text { kawasan berupa mobil, } \\
\text { sepeda motor, bus, } \\
\text { angkutan umum dan ojek }\end{array}$ & & $\begin{array}{l}\text { ada perkerasan jalan dan } \\
\text { masih tanah }\end{array}$ \\
\hline
\end{tabular}

*Sumber: Data Primer dan Sekunder, 2020; BPS Kota Salatiga, 2021

\subsection{Hasil Wawancara}

Wawancara dilakukan kepada pengasuh Panti Asuhan dan pengurus Yasasan dengan mengajukan beberapa pertanyaan sesuai pedoman pertanyaan yang telah di persiapkan sebelumnya, aspek pertanyaan dan hasil wawancara dapat di lihat pada tabel 4.

Tabel 4. Inventarisasi Persepsi, Preferensi, dan Ekspektasi Pengurus dan Pengasuh Panti Asuhan Salib Putih

\begin{tabular}{|c|c|c|c|c|}
\hline & Aspek & Pengurus Yayasan & Pengasuh Panti Asuhan & Analisis \\
\hline 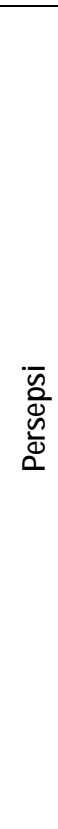 & Kepentingan & $\begin{array}{l}\text { Salah satu fasilitas yang } \\
\text { idealnya memang seharusnya } \\
\text { ada di sebuah Panti Asuhan } \\
\text { untuk mendukung tumbuh } \\
\text { kembang mereka karena dunia } \\
\text { anak adalah dunia bermain } \\
\text { akan tetapi bermain juga bisa } \\
\text { sambil belajar. Selain itu } \\
\text { Sebagai sarana agar anak- } \\
\text { anak tidak bosan dan bersedih } \\
\text { karena mereka harus tinggal di } \\
\text { Panti Asuhan dan harus } \\
\text { memiliki kehidupan yang } \\
\text { berbeda dengan anak-anak } \\
\text { diluar sana. }\end{array}$ & $\begin{array}{c}\text { Untuk mewadahi anak- } \\
\text { anak dalam bermain, } \\
\text { bermain menjadi tambah } \\
\text { menarik dan } \\
\text { menyenangkan, serta } \\
\text { menghilangkan kebosanan } \\
\text { saat berada di Panti } \\
\text { Asuhan } \\
\text { Anak-anak bisa lebih } \\
\text { bersosialisasi dengan } \\
\text { teman-temannya dengan } \\
\text { bermain bersama, karena } \\
\text { permainan sekarang } \\
\text { cenderung permainan } \\
\text { individual sebagai contoh } \\
\text { game onine dan } \\
\text { permainan gadget Tidak } \\
\text { melakukan permainan } \\
\text { atau bermain yang } \\
\text { membahayakan bagi } \\
\text { mereka dan orang lain, }\end{array}$ & $\begin{array}{c}\text { Selain sebagai sarana untuk bermain } \\
\text { bagi anak-anak Panti Asuhan, juga } \\
\text { dapat digunakan bagi pengunjung } \\
\text { panti/ donatur yang mengajak anak } \\
\text { mereka berkunjung serta } \\
\text { memanfaatkan lahan/space yang } \\
\text { masih luas } \\
\text { Permainan outdor dalam children } \\
\text { playground akan membangkitan sosial } \\
\text { anak, sehingga anak-anak secara } \\
\text { langsung akan bersosialisasi dengan } \\
\text { teman-teman di panti asuhan dalam } \\
\text { melakukan permainan bersama, } \\
\text { sehingga keakraban dan kekeluargaan } \\
\text { akan semakin tumbuh terjalin satu } \\
\text { sama lain. }\end{array}$ \\
\hline
\end{tabular}




\begin{tabular}{|c|c|c|c|}
\hline Aspek & Pengurus Yayasan & Pengasuh Panti Asuhan & Analisis \\
\hline $\begin{array}{l}\text { Kesan yang } \\
\text { ingin dicapai }\end{array}$ & $\begin{array}{c}\text { Dapat menghilangkan } \\
\text { kesedihan anak serta dapat } \\
\text { membangkitkan semangat } \\
\text { anak-anak. }\end{array}$ & $\begin{array}{c}\text { Taman yang ceria dan } \\
\text { dapat digunakan kegiatan } \\
\text { outdor Bersama }\end{array}$ & $\begin{array}{c}\text { Permainan yang seru dan menarik } \\
\text { dapat menghilangkan kesedihan anak- } \\
\text { anak di Panti Asuhan yang } \\
\text { dikombinasi dengan area untuk } \\
\text { kegiatan outdor Bersama semacam } \\
\text { api unggun dsb. } \\
\end{array}$ \\
\hline Fasilitas & $\begin{array}{l}\text { Fasilitas permainan yang } \\
\text { diprioritaskan adalah } \\
\text { permainan-permainan yang } \\
\text { memiliki resiko bahaya yang } \\
\text { minim sehingga keselamatan } \\
\text { anak dalam bermain yang } \\
\text { menjadi hal utama. Fasilitas } \\
\text { pendukung antara lain gazebo, } \\
\text { tempat cuci tangan, tempat }\end{array}$ & $\begin{array}{l}\text { Permainan yang menarik } \\
\text { dan bermacam-macam } \\
\text { pada area Children } \\
\text { Playground. Tempat cuci } \\
\text { tangan dibeberapa sudut, } \\
\text { gazebo untuk belajar dan } \\
\text { berdoa/renungan } \\
\text { Bersama, kolam ikan }\end{array}$ & $\begin{array}{l}\text { Untuk bermacam fasilitas baik utama } \\
\text { maupun pendukung dapat di sematkan } \\
\text { atau aplikasikan pada desain hanya } \\
\text { saja tergantung dengan luasan tapak } \\
\text { yang tersedia sehingga akan di } \\
\text { prioritaskan kembali dan akan } \\
\text { mengacu pada aspek fungsi dari } \\
\text { fasilitas utama maupun fasilitas } \\
\text { pendukung itu sendiri. }\end{array}$ \\
\hline
\end{tabular}

sampah, penerangan dimalam

hari, kendang hewan (kelinci, anjing, dll) dan kolam ikan Konsep yang diinginkan adalah sebuah tempat bermain yang dapat membangkitkan semangat dan meningkatkan keceriaan anak-anak Panti Asuhan dan memiliki taman dengan bunga warna-warni

Konsep yang diinginkan adalah tempat bermain yang memiliki permainan yang beragam dan memiliki taman dan dapat juga digunakan untuk kegiatan outdor Bersama
Konsep dan tujuan utama berbagai macam fasilitas bermain ini adalah untuk membuat anak-anak bahagia dan ceria, tidak hanya bermain tetapi anak-anak juga bisa memelihara hewan peliharaan baik itu bermain dengan hewan peliharaan ataupun memberi makan dipadukan dengan taman tropis

$\begin{array}{cc}\text { Pembangunan dapat } & \text { Pembangunan dapat dilakukan secara } \\ \text { direalisasikan secara } & \text { bertahap, dapat dimulai dari fasilitas } \\ \text { bertahap } & \text { utama yang memang benar-benar } \\ \text { diprioritaskan untuk dibangun terlebih } \\ \text { dahulu, kemudian diiringi } \\ \text { pembangunan fasilitas pendukung, } \\ \text { serta penanaman vegetasi pada area } \\ \text { tempat bermain. }\end{array}$

Harapannya fasilitas bermain ini dapat meningkatkan semangat anak-anak dan menambah keceriaan didalam Panti Asuhan Salib putih
Melengkapi area bermain dengan berbagai macam permainan yang sudah direncanakan sebelumnya serta fasilitas penunjang dan penanaman vegetasi. pemban meran disa dalam area tempat beremain itu sendiri.

*Sumber: Data hasil Inventarisasi Persepsi, Preferensi dan Ekspektasi yang diolah, 2020

\subsubsection{Persepsi Pengurus Yayasan dan Pengasuh Panti Asuhan}

Berdasarkan pendapat Pengurus Yayasan, aspek secara fungsi dari Children Playground adalah dapat memfasilitasi kegiatan bermain anak-anak selama tumbuh kembang mereka di Panti Asuhan. Selain itu juga memanfatkan lahan atau space yang menurut pengelolla memang masih cukup luas dan belum dimanfaatkan serta juga dapat menambah daya tarik pengunjung Panti Asuhan yang datang serta membawa anak-anak mereka yang masih kecil. Kemudian tidak lupa juga untuk meningkatkan dan menambah nilai estetika pada area Panti Asuhan Salib Putih. Hal serupa juga sejalan dengan hasil wawancara kepada pengasuh Panti Asuhan yang menginginkan adanya sebuah ruang khusus atau Children Playground untuk menjadian sebuah wadah bagi anak-anak bermain yang selama ini pihak Yayasan mengakui memang belum terfasilitasi dengan baik.

Pada persepsi yang dilihat menurut aspek kepentingan, Pengurus Yayasan beranggapan bahwa idealnya memang sebuah Panti Asuhan memiliki sebuah tempat bermain bagi anak-anak untuk mendukung 
tumbuh kembang mereka selama berada di Panti Asuhan Salib Putih. Menurut pengasuh Panti Asuhan Salib Puth dunia anak merupakan dunia bermain akan tetapi kegiatan bermain juga bisa di iringgi dengan belajar. Selain itu menurut pengasuh Panti Asuhan hal tersebut juga dapat sebagai sarana agar anak-anak tidak bosan dan jenuh selama berada di Panti Asuhan. Aktivitas bermain memiliki sitnifikasi terhadap anak dan peran penting untuk memperlajari dunia sekitar, area bermain dan fasilitas utama serta fasilitas pendukung berfungsi untuk mendukung pengalaman rekreasional dan kesenangan pada anak (Bell dkk,2011). Anak-anak memanfaatkan halaman depan panti asuhan dan halaman belakang untuk sekedar bermain sepak bola, bermain kelereng dan petak umpet. Mereka juga sering bermain di teras halaman untuk dan aula apabila aula sedang tidak digunakan acara di Panti Asuhan.

Pada persbesi yang dilihat menurut kesan yang ingin di tonjolkan dalam desain menurut pengurus Yayasan dan Pengasuh Panti Asuhan adalah sebuah taman bermain yang dapat menghilangkan kesedihan anak serta dapat membangkitkan semangat anak-anak panti.

\subsubsection{Preferensi Pengurus Yayasan dan Pengasuh Panti Asuhan}

Pada preferensi yang dilihat menurut aspek fasilitas pengurus mengiunginkan Fasilitas permainan yang diprioritaskan dalam desain Children Playground adalah permainan-permainan yang memiliki resiko bahaya yang minim sehingga keselamatan anak dalam bermain menjadi hal yang utama. Selain utama Fasilitas pendukung seperti gazebo, tempat cuci tangan, tempat sampah, penerangan dimalam hari, kendang hewan (kelinci, anjing, dII) dan kolam ikan dapat di sematkan dalam desain Children Playground.

Pada aspek konsep, kesan yang ingin diwujudkan dalam desain adalah suasana yang semangat dan ceria, hal tersebut diharapkan dapat mengusir kesedihan mereka karena mereka harus jauh dari kedua orang tua bahkan harus ditinggal orang tua mereka dan keadaan yang memaksa mereka harus tinggal di sebuah Panti Asuhan dan harus memiliki kehidupan yang berbeda dengan anak-anak diluar sana. Cass, 1974 dalam Catron \& Allen, 1999 (dalam Musfiroh, Tadkiroatun 2005: 18) mengatakan bahwa bermain dapat membantu perkembangan emosi yang sehat dengan cara menawarkan kesembuhan dari rasa sakit serta kesedihan. Melalui bermain, anak belajar menyerap, mengekspresikan, dan menguasai perasaan mereka secara positif dan konstruktif, sehingga melalui kegiatan bermain anak-anak setidaknya dapat melupakan latar belakang sejenak saat dan mereka dapat lebih bersemangat dan melupakan kesedihan mereka sehingga mereka akan lebih fokus dalam mengapai cita-cita untuk masa depan mereka. Menurut pendapat pengasuh Panti Asuhan, desain yang diinginkan adalah taman yang memiliki berbagai macam permainan yang menarik dapat miningkatkan antusias mereka untuk bermain, sehingga mereka tidak akan jenuh berada di Panti Asuhan. Menurut Korczak, dkk (2017:139) bermain dapat mengurangi stres, kelelahan, cedera dan depresi dan meningkatkan jangkauan gerak, kelincahan, koordinasi, keseimbangan, dan fleksibilitas. Area bermain dapat dipadukan dengan sebuah taman dengan bermacam vegetasi yang beragam, dengan taman bergaya tropis di berbagai suduh halaman Panti Asuhan. Taman bergaya tropis ini cocok diterapkan di negara beriklim tropis seperti Indonesia, banyak tanaman yang tumbuh subur di iklim tropis sehingga memungkinkan untuk memilih beragam jenis tanaman. Selain itu juga data ditambahkan sebuah area untuk hewan peliharaan atau sebuah kendang seperti kandang anjing, kelinci, burung, atau bahkan kolam ikan menurut pengasuh Panti Asuhan juga dapat menambah daya tarik pada tapak untuk anak-anak bahkan pengunjung Panti Asuhan, selain itu juga dapat melatih tanggung jawab anak-anak sejak dini karena secara langsung mereka akan bertanggung jawab memelihara dan memberi makan.

\subsubsection{Ekspektasi Pengurus Yayasan dan Pengasuh Panti Asuhan}

Ekspektasi pengurus Yayasan yang dilihat dalam jangka pendek ini adalah mewujudkan Children Playground agar terealisasikan sehingga dapat megakomodir anak-anak bermain dengan baik walapun dengan pembangunan yang bertahap dan tidak harus 100\% pembangunannya selesai. Pembangunan dapat dilakukan secara bertahap, dapat dimulai dari fasilitas utama yang memang benar-benar diprioritaskan untuk dibangun terlebih dahulu, kemudian dapat diiringgi pembangunan fasilitas pendukung, serta penanaman vegetasi pada sudut area tempat bermain. Sedangkan Ekspektasi para Penggurus secara jangka Panjang Fasilitas permainan ini dapat dilengkapi sehingga antusias anak-anak akan semakin tinggi dan fasilitas penunjang seiring pembangunan bisa dilengkai dengan berbagai kebutuhan dalam area tempat beremain itu sendiri sehingga kebutuhan Fasilitas bermain anak-anak di Panti Asuhan Salib Putih dapat terfasilitasi dengan baik

\subsection{Hasil kuesioner}


Hasil kuisioner yang diberikan kepada 40 responden diolah menggunakan Excel sehingga dapat dilihat pada tabel 5. Hasil kuisioner kemudian di kaitkan dengan kategori skala pada tabel 1 serta melihat garis kontinum agar memudahkan dalam megkategorikan variabel. Pada poin pertama mengenai seberapa penting kehadiran sebuah Children Playground untuk anak-anak di Panti Asuhan Salib Putih sebanyak 29 responden sangat setuju dengan dibangunnya area bermain bagi anak-anak panti, 10 responden memilih setuju dan 1 reponden netral dengan kata lain 39 setuju dengan bobot 4.7 maka dikasifikasikan pembangunan Children Playground sangat penting (SP). Pada pertanyaan yang kedua mengenai fasilitas pendukung berupa tempat duduk sebanyak 22 responden memilih sangat setuju dan 18 memilih setuju, sehingga fasilitas tempat duduk pada area Children Playground memiliki bobot 4.55 dengan kategori sangat penting (SP), sedangkan pada fasilitas penerangan lampu sebanyak 23 responden memilih sangat setuju, 11 reponden setuju, 3 reponden netral, dan 3 responden tidak setuju reponden beranggapan bahwa area bermain sebaiknya digunakan pada pagi hari sampai sore hari sehingga penerangan lampu tidak perlu, namun setelah dihitung bobot yang di peroleh sebesar 4.35 dengan kata lain fasilitas penerangan lampu sangat penting (SP).

Tabel 5. hasil kuesioner kepada responden terhadap aspek fasilitas utama dan pendukung

\begin{tabular}{|c|c|c|c|c|c|c|c|c|c|}
\hline \multirow[b]{2}{*}{ Pertanyaan } & \multirow[b]{2}{*}{ Indikator } & \multicolumn{5}{|c|}{ Tanggapan Responden } & \multirow[b]{2}{*}{ Jumlah } & \multirow[b]{2}{*}{ Bobot } & \multirow[b]{2}{*}{ Keterangan } \\
\hline & & $\begin{array}{l}\text { STS } \\
\text { (1) }\end{array}$ & $\begin{array}{l}\text { TS } \\
\text { (2) }\end{array}$ & $\begin{array}{c}\mathrm{N} \\
\text { (3) }\end{array}$ & $\begin{array}{c}\text { S } \\
\text { (4) }\end{array}$ & $\begin{array}{l}\text { SS } \\
\text { (5) }\end{array}$ & & & \\
\hline 1 & Childern Playground & 0 & 0 & 1 & 10 & 29 & 188 & 4.7 & SP \\
\hline 2 & Tempat duduk & 0 & 0 & 0 & 18 & 22 & 182 & 4.55 & SP \\
\hline 3 & Penerangan Lampu & 0 & 3 & 3 & 11 & 23 & 174 & 4.35 & SP \\
\hline 4 & Tempat Cuci Tangan & 0 & 0 & 5 & 13 & 22 & 177 & 4.425 & SP \\
\hline 5 & Sign & 0 & 3 & 1 & 18 & 18 & 171 & 4.275 & SP \\
\hline 6 & Pedestrian & 0 & 1 & 11 & 25 & 3 & 150 & 3.75 & $P$ \\
\hline 7 & Gazebo & 0 & 1 & 3 & 30 & 6 & 161 & 4.025 & $P$ \\
\hline 8 & Peneduh & 0 & 3 & 0 & 22 & 15 & 169 & 4.225 & SP \\
\hline 9 & Kandang Hewan & 0 & 0 & 15 & 14 & 11 & 156 & 3.9 & $P$ \\
\hline
\end{tabular}

Keterangan: STS (sangat tidak setuju), TS (tidak setuju), N (netral), S (setuju), SS (sangat setuju), SP

(sangat penting), $P$ (penting)

Fasilitas tempat cuci tangan menurut 22 reponden sangat setuju, 13 reponden setuju dan 5 reponden netral bila dijumlahkan maka bobot yang diperoleh adalah 4.42 sehingga fasilitas tempat cuci tangan dikategorikan sanggap perlu (SP). Kemudian fasilitas pendukung sign atau papan penunjuk arah bisa juga berisikan kata-kata motifasi, sebanyak 18 reponden memilih sangat setuju, 18 reponden setuju, 1 reponden netral dan 3 reponden tidak setuju karena menurut beberapa reponden area tapak yang ada sangat terbatas, sehingga fasilitas sign memiliki bobot 4.27 dengan kategori sangat perlu (SP). Pada pertanyaan selanjutnya yang menanyakan seberapa perlu variasi pedestrian untuk yang sudah karena pedestrian yang sudah ada kurang menarik dan terkesan kaku, sebanyak 3 reponden sangat setuju, 25 reponden memilih setuju, 11 netral dan 1 reponden memilih tidak setuju, beberapa beranggapan bahwa hal tersebut kurang penting dan akan lebih memakan biaya, vareasi pedestrian memiliki bobot 3.75 dengan kategori penting $(P)$.

Pada pertanyaan selanjutnya yang menanyakan seberapa penting fasilitas gazebo pada area Children Playground, sebanyak 6 reponden memilih sangat setuju, 30 responden memilih setuju3 reponden memilih netral, dan 1 reponden memilih tidak setuju. Sebagian besar beranggapan bahwa fasilitas gazebo dapat menambah daya tarik dan meningkatkan nilai estetika, fasilitas gazebo ini memiliki bobot sebesar 4.02 sehingga tergolong penting $(P)$. Pertanyaan selanjutnya mengenai seberapa penting peneduh pada area Children Playground sebanyak 15 reponden beranggapan sangat penting, 22 reponden memilih penting dan 3 reponden memilih tidak penting. Karena mereka berpendapat bahwa halaman sangat dekat dengan Gedung Panti Asuhan sehingga tidak perlu adanya peneduh pada ara bermain, namun setelah dihitung fasilitas peneduh memiliki bobot sebesar 4.25 sehingga dikategorikan sangat penting (SP). Soal terakhir mengenai seberapa penting area untuk hewan peliharaan seperti kendang kelinci, kendang anjing ataupun kola mikan 
sebanyak 11 reponden memilih sangat setuju, 14 reponden memilih setuju dan 15 reponden netral, dapat dilihat pertanyaan ini memiliki hasil bobot sebesar 3.9 dengan ini dapat dikategorikan bahwa fasilitas berupa tempat untuk hewan peliharaan ini perlu (P) untuk di sematkan pada desain Children Playground.

Dari keseluruhan indikator atau pertanyaan yang diajukan kepada reponden disimpulkan bahwa fasiltas pendukung dan fasilitas utama (tabel 3), responden menyatakan bahwa dari indikator tersebut sangat perlu untuk di adakan dalam Children Playground Panti Asuhan Salib Putih.

\section{Kesimpulan}

1. Hasil penelitian menunjukan bahwa hasil analisis biofisik pada area tapak di Panti Asuhan Salib Putih yang akan didesain sebagai Children Playground layak dan berpotensi untuk dijadikan sebuah area bermain atau Children Playground bagi anak-anak di Panti Asuhan Salib Putih karena melihat dari lokasi yang aman dan nyaman, memiliki tanah yang datar dan subur serta beriklim sejuk

2. Dari hasil kuisioner kepada 40 reponden serta wawancara mengenai persepsi, preferensi dan ekspektasi kepada Pengurus Yayasan dan Pengasuh Panti Asuhan setuju untuk dibangunnya Children Playground dengan mengutamakan desain Children Playground yang aman bagi anak-anak di Panti Asuhan Salib Putih dengan dilengkapi berbagai fasilitas pendukung seperti tempat cuci tangan, Gazebo, tempat sampah, kandang untuk hewan peliharaan (anjing, kelinci, kolam ikan) serta penerangan lampu dimalam hari.

\section{Daftar Pustaka}

Asmawati, Luluk. (2011). Pengelolaan Pengembangan Anak Usia Dini. Universitas Terbuka. Jakarta.

Baskara, Medha. (2011). Prinsip Pengendalian Taman Bermain Anak di Ruang Publik. Jurnal Landskap Indonesia 3(1):27-34.

Bell, P.A., Greene, T.C., Fisher, J.D. \& Baum, A. (1996). Environmental Psychology. Forth Worth, Harcourt Brace. Texas.

BPS Kota Salatiga. (2020). Data curah hujan 2010-2019. Salatiga, "https://salatigakota.bps.go.id/indicator/151/100/1/curah-hujan.html diakses 24 januari 2021.

Brown, F. (2003). Playwork: Theory and practice. Buckingham, UK: Open University Press.

Korczak DJ, Madigan S, Colasanto M. (2017). Children's physical activity and depression: a meta-analysis. Pediatrics, 139(4):e20162266

Lippsmeier, Georg. (1994). Tropenbau Building in the Tropics, Bangunan Tropis (terj.). Erlangga. Jakarta.

Moleong, Lexy. (2005). Metodologi Penelitian Kuantitatif. PT Remaja Rosdakarya. Bandung

Musfiroh, T. (2014). Teori dan konsep bermain. Universitas Terbuka, 1-44.

Rodger, S. \& Ziviani, J. (2006). Occupational Theraphy with Children: Understanding Children's Occupations and Enabling Participation. Blackwell Publishing Ltd. Oxford. UK.

Sugiyono. (2014). Metode yogPenelitian Kuantitatif, Kualitatif, dan R\&D. Alfabeta. Bandung.

Yogman, M., Garner, A., Hutchinson, J., Hirsh-Pasek, K., Golinkoff, R. M., \& Committee on Psychosocial Aspects of Child and Family Health. 2018. The power of play: A pediatric role in enhancing development in young children. Pediatrics, 142(3).ba 